\title{
A FUNCTIONAL SYSTEM OF ADAPTIVE DISPERSAL BY FLIGHT ${ }^{1}$
}

\author{
By C. G. Johnson \\ Rothamsted Experimental Station, Harpenden, Herts., England
}

Insect dispersal is a confused subject and lacks system. This confusion is not entirely the result of the diversity of insects but of the ill-defined concept of dispersal. Insects move in different ways, resulting in different patterns of dispersion which can be characteristic of the species within a habitat (151). For example, adult insects gather together temporarily to rest, feed, mate, lay eggs, or to hibernate; the immature stages are also spatially distributed in certain ways (151). These patterns periodically disintegrate and reform. Within wide areas populations mix rather than disperse. This periodic disintegration of the population pattern in its breeding habitat is the process of dispersal and migration, and more of it is adaptive and less accidental than has been thought.

It cannot be assumed that insects released artificially from point sources simulate natural populations; and until the natural sources, the populations, the physiological states of individuals, and the areas are defined, there is little chance of making a system which describes how biological and ecological processes, and the statistical distributions they cause, are associated in nature.

Most entomologists work with a few closely related species, and many general assumptions about dispersal (and "migration" with which it is linked) stress features which, though spectacular, are specialized rather than general. A multitude of terms has resulted (vagrancy, nomadism, dissemination, etc.) that confuse rather than clarify the subject $(17,69,155)$. A general system for dispersal seems to be needed; such a system must first delineate the working of the process and seek to identify the main and the subsidiary processes whose effects on distribution might later be expressed mathematically. This is the aim of this article, which also tries to characterize migration and adaptive dispersal physiologically and ecologically, as well as behaviourally.

\section{THE MAIN THESIS}

With few exceptions, it is primarily winged adults, especially females, that redistribute populations adaptively and periodically beyond the breeding place. It is their main function.

The primary source is the breeding population, and the main dispersal flight (or flights) usually begin with young, sexually immature females at their birthplace or nearby. These insects seem particularly adapted to flights, lengthy for the species, and are relatively undistracted by the need to rest,

${ }^{1}$ The survey of literature pertaining to this review was concluded in February 1965. 
feed, or lay eggs. At exodus, and later, orientation is adapted to get them out and beyond the birthplace to another oviposition site. As the need to lay eggs grows, flight of ten seems to be more local, and presumably less widely dispersive (83). Dispersal by other stages is, in general, subsidiary to this. There are, however, important exceptions which will be discussed.

\section{BACKGROUND AND PRESENT APPROACH}

Different people have seen migration and dispersal as distinct: processes, twice reviewed in these volumes. Williams reviewed a special class of adaptive flight, namely, when insects move unidirectionally en masse, seemingly able to control their direction for relatively long distances (168). He called these migrations. By contrast, he saw dispersal mainly as a passive and accidental process as when insects are scattered by wind. This view is still common.

A broader view of migration expounded by Kennedy was recognized, though not completely accepted, in the second review by Schneider (136). This view regards mass flights, like those of aphids (formerly regarded as passive), as active and adapted to displace populations by wind which controls the direction of travel; it characterizes migration behaviourally as an accentuation of locomotor function with a depression of vegetative function. Many classical migrants once thought able to control the direction of their migration, such as locusts and some butterflies, now come into this category of adaptive wind-borne travellers, and when wind takes control it usually disperses, swarm locusts being a notable exception. Also, dispersal occurs as insects drop out en route $(153,156)$. In this review, therefore, migration and flight adapted for dispersal per se are regarded as synonymous.

Nevertheless, insects do disperse accidentally, or (presumably) incidentally while obtaining food or mates, or by other activities, in a quiet, continuous and humdrum way that Elton thought general among animals. Andrewartha \& Birch accepted this but thought animals also had an innate terdency to disperse though they did not specify how; with insects, that ter.dency was phased with the other activities of adult life (4).

It is extremely difficult to measure how much dispersion occurs accidentally, incidentally, or adaptively, for such movements are usually indistinguishable in nature. But the mass movements, usually called migratory, stand out as probably the most important. Therefore if a general, valid, and functional system for all of these movements can be made, it may show up effects of incidental and accidental movements in clearer perspective (I suggest that these are small by comparison with those of adaptive movements).

\section{PERSPECTIVES OF THE SYSTEM}

The system starts at the birthplace of adults; it is concerned mainly with females, and migratory or dispersive performance is governed considerably by the life span of the adult. 


\section{Migration by Males and Females}

It is of ten assumed that males and females migrate similarly. However, they do not. Migratory populations always contain females from the beginning to the end of a migration. Males perform more variably.

With some species both sexes migrate from source to destination while sexually immature, maturing together and mating at the end of the journey (Schistocerca gregaria Forskål) $(118,119)$. With others, like Eurygaster integriceps Putnam, sexually immature males and females fly from the birthplace to hibernation sites but males mature and mate after hibernating, with immature females that mature more slowly and migrate back to breeding areas (20). Males of Danaus plexippus mature soon after beginning to migrate but nevertheless accompany immature females hundreds of miles, mating with them before hibernating (43). Males of Aedes taeniorhynchus (Wiedemann) mate at exodus and fly only a very short distance, leaving the immature females to migrate alone for many more miles $(63,122)$. The females of the moth Rhyacionia buoliana (Schiffermueller) do not normally migrate until fertilized soon after emergence (59). Parthenogenetic aphids need no male.

The main migratory role thus belongs, generally, to the female. It is her function to lay eggs when she gets to a new habitat. This timing is ensured generally by her sexual immaturity at exodus, though this is modified in some species. The role of the male is merely to fertilize the female; and that can be arranged anywhere. Thus, generalizations are more applicable to females, whereas males present special problems.

\section{Migration in Relation to Adult Life-Span}

All types of migration or adaptive dispersal can be classificd into three types, on the basis of the adult life-span.

Type I: short-lived adults that emigrate and die within a season.-Most of these insects fly from the birthplace, lay eggs elsewhere and die without returning. This is achieved by many types of migratory flight. For example, the long distance, wind-borne, speedy flight of locusts; the short, weak flight of termites; the slow, wind-borne flight of thrips and aphids; and the classical linear migration flights of many butterflies. The majority of such emigrations are dispersive.

Type II: short-lived adults that emigrate and return.-Females fly from the birthplace to feeding and oogenesis sites, mature eggs there and then fly back to the former (or nearby) places to oviposit. The to and fro journey may be repeated more than once by the same individual. Examples are Melolontha melolontha (L.) and many Odonata $(34,135)$.

These flights may not be migratory in the sense that the insects are undistracted in flight (as many migrants characteristically are) and normally they tend to concentrate rather than to disperse the population. But occasionally longer flights beyond the habitat occur [e.g., "beeliners" a mong Phyllopertha horticola (L.) $(107,108)]$ and most migratory flights of dragonflies 
are probably extensions of the post-teneral exodus flight $(34,82)$ : both of these seem to be truly migratory in the ecological and behavioural senses and eventually are dispersive.

Type III: long-lived adults that hibernate or aestivate.-Flights from birthplace to hibernation or aestivation sites usually end, not in dispersion but in aggregation; but when the process is continued with so-called "return migration" in the next season, it is usually dispersive. Examples are many Coleoptera, e.g., Hippodamia convergens Gúerin (64) and D. plexippus (156), and many Noctuidae, e.g., Agrotis infusa Boisduval (30). Some do most of the migrating before hibernation [as with Leptinotarsa decemlineata Say in North America and some parts of Europe $(154,166)]$, others mostly afterwards. Among the latter, some even hibernate where they become adult, dispersing only afterwards [Conopithorus coniperda (Schwarz) (71)].

Also, the distinction between Types I and II is sometimes blurred, depending on whether most fying is done before or after feeding and oogenesis; thus, some mosquitoes fly three or four miles after emergence and orly then feed and redisperse--some apparently even returning from whence they came [e.g., Mansonia perturbans (Walker) (141)]. Little seems to be known about relative distances travelled by many insects before and after oviposition, or between egg laying by the same individuals; but the emigration after pupal emergence (often characterized by a relatively prolonged and undistracted flight), is often the most noticeable with recognized migrants. This is the typical "migratory" flight, during which many responses, especially those of feeding and oviposition, are diminished temporarily.

\section{PARTS OF THE SYSTEM}

\section{Place of Origin}

There are two fundamentally different types of "populated place" (4) from which dispersal occurs adaptively. Most important is the site where new adults develop. There, during their development, the insects make demands on the habitat and change it. These changes, and those caused by the seasons affect the insects' ontogeny and apparently determine whether or not, or in what proportions, adults will become migrants, and hence the extent and amount of dispersal.

The second type of "place" is of secondary importance. It is not a birthplace but some other site where adults assemble. If Type II movements are migratory in the senses defined earlier (and this is debatable), feeding and oogenesis sites are among these. Otherwise the principle ones are hibernation and aestivation sites. In these sites the adults are already migrant having come from a breeding site; they merely remain there temporarily, making few or no demands on the place and ultimately move from it dispersively.

It is therefore with the adult's birthplace that a functional system begins; thereafter follows the sequence of events in the adult's life leading to its death elsewhere. 


\section{ExoDus}

There are a few observations of the beginnings of "classical" migrations especially of butterflies and dragonflies; rather more exist for migratory insects in the wider sense, including wind-borne dispersants formerly considered to be "passive." But, of the vast majority of even well known and common species, nothing is known about exodus behaviour though it is very important for dispersal. Most commonly recognized mass dispersals begin not only at the adult's birthplace or nearby, but relatively soon after the adult emerges, and on an early, often the first, flight (82). The prime function of such flights is departure, sometimes for long distances, as soon as the insects become fully flight-mature. References to this type of dispersal, or in support of it in various orders, are made in the following: Odonata (34); Orthoptera $(62,124)$; Isoptera (77); Psocoptera (114); Homoptera: Aphididae $(80,91)$ Cicadellidae $(31,97,112)$, Psyllidae (167); Heteroptera $(10,20,50$, $86,147,160)$; Lepidoptera $(1,14,16,59,110,113,130,139,153,156,161$, 162); Trichoptera (36); Coleoptera (27, 53, 108, 125, 128, 140, 154, 158); Diptera $(38,63,134,146)$; Hymenoptera $(8,106,148)$.

There are more references it seems to the positive act of exodus (few though these are) than to others showing that adults do not leave, and it would be instructive to search out the latter. Some examples, from various orders, of insects that do not disperse widely after emerging are as follows: Odonata (34); Lepidoptera $(49,137)$; Coleoptera $(107,108)$; Hemiptera $(92)$; Orthoptera (9).

It is recognized that, although winged adults almost invariably fly soon after becoming adult, such flight does not necessarily imply an adaptive dispersal (88). The point made here is that migratory flights or the sudden disappearance of large adult populations do not usually happen after the alates have already spent part of their lives flying about inside the habitat or territory. Significant dispersal, when it begins, is usually an early, even the first, main act.

Drosophila pseudoobscura Frolowa populations gradually diffuse (42), though a migratory phase has been claimed for other species (44). The nonmigratory form of the butterfly Ascia monuste L. diffuses gradually, nevertheless largely by the young (110)

Clearly, the system is graded. Adaptive dispersants or migrants however, do not have a "natural resistance... to any movement away from their food and shelter habitat" (24) if that is the place where they were born, until some adverse factor drives them out. A major problem is to obtain more information on exodus behaviour both with migrant and so-called nonmigrant forms of the same species.

The exodus flight.-Descriptions of flights at exodus, of several widely differing species (often accepted migrants) indicate a characteristic behaviour, different from what would be expected if exodus was casual. Flight is often almost vertical or at a steep angle and often spiral until between 20 and 
$40 \mathrm{ft}$ above the ground; after this the insects depart either in a linear, orientated flight (which may later become wind-directed), or they become immediately wind-borne. Examples of the initial upward and then linear flight have been described for the following:

Odonata Anax imperator Leach (32).

Coleoptera Limonius californicus (Mann.) (138); Melolontha hippocastani Fabricius and $M$. vulgaris Fabricius $(35,135) ;$ Phyllopertha horticola (107, 108); Conophthorus coniperda (72); Trypodendron lineatum (Oliver) (58); Hippodamia convergens (64); Priacma serrata (Lecomte) (5).

Lepidoptera Hemileuca oliviae Cockerell (3); Agrotis infusa Boisduval (30).

Heteroptera Corixa geoffroyi Leach and C. fabricius (Fieber) (95, 104); Dysdercus sidae Montr. (10).

Diptera Aedes taeniorhynchus (63); Aedes cataphylla Dyar (94).

Examples of insects becoming wind-borne after the elevating flight are: $H$. convergens (64); Oscinella frit (L). (146); A phis fabae Scopoli and My:zus persicae (Sulzer) (91); Limothrips cerealium Haliday (100); Choristonetura fumiferana Clemens (14); Plusia gamma L. (2, 96, 142); Rhyacionia buoliana (60). In some of the above insects, such flights can occur also after hibernation or aestivation.

There is of ten a preliminary aggregation fairly high in the air in which many insects "mill around" in flight before migrating. This occurs characteristically and dramatically with swarm locusts (62), A.taeniorhynchus (63), and also with Ascia monuste L. (110), Corixa geoffroyi Leach (104), D. plexippus (156), M. melolontha (135), Myrmica emeryana Forel (106) and probably Simulium venustum Say, and S. vittatum Zetterstedt (74). It is not to be confused with mating swarms (though mating accompanies it at least in Aedes and Myrmica). This behaviour might account for the belief that inserts "assemble" like birds before migrating. Actually, this is not so, the mass exodus being primarily a consequence of mass emergence, (or secondarily after aggregation at hibernation or aestivation sites with some species).

"Post-teneral" and other types of exodus.-There has been some criticism of the idea that post-teneral migration is general (136), principally because insects migrate also after hibernating, or because migration is said to be clelayed beyond the end of the so-called "teneral period" (20), or because some migratory flights continue long after primary exodus as a mong locusts. These criticisms do not invalidate the general importance of post-teneral migration, which is very widespread and usually occurs also among insects that hibernate (Type III), though in an extreme instance like Conophthorus migration is suspended until after hibernation which actually occurs at the emergence site (71). Most insects that migrate inter-reproductively or continually, like frit flies, also begin "post-tenerally."

The term, "teneral" (= tender) is not to be taken too literally in this context. Dragonflies migrate while the cuticle is still soft and the abdomen droops (32). Locusts continue to develop pigment after exodus $(124,163)$. 
Pierids can fly two hours after emerging but the cuticle is not at its maximum hardness. Eurygaster integriceps needs several days to fill the fat body before migrating (20). The hardening of cuticle, pigmentation, filling of fat body, integration of enzyme systems in flight muscles [metachemogenesis (129)], are variably phased, and the term "teneral" is vague and arbitrary. The fact remains, that most migrations normally begin as soon as the insect is flight-mature; and apparently not after the insect has had a lengthy period of other kinds of flying.

Synchronization of exodus.--Most mass migrations (especially of Type I) are synchronized at primary exodus following mass emergence. Some synchronization of return flights from oogenesis sites occurs in Type II, notably with aggregated flights of dragonflies returning to oviposit (34), or after hibernation or aestivation $(30,145)$.

Primary exodus from birthplace can be synchronized seasonally in several ways. The population can "pile up" in the last, diapausing instar so that a large proportion of adults emerge more or less together. Synchronized emergence could also occur if successive instars each had successively higher development temperature thresholds, and, as weather became warmer, adults emerged over a short period (34). Adults develop synchronously from eggs laid locally by passing migrants (10); some emerge to pile up inside a gall or termitarium until they are released by suitable weather, as with species of Adelges and with termites.

Within the seasonal curve, synchronized diel flight periodicities are of many types. Recently, 400 taxa have been exhaustively classified, and analyzed. Normally at exodus, flight periodicity is controlled by the periodicity of emergence (which may be affected by endogenous factors), the length of the teneral period as affected by temperature and the operation of light and temperature thresholds for takeoff, endogenous processes being obscured (102). The system has been worked out in great detail for A phis fabae (84). Normally, with most day-flying insects, temperature controls the start of takeoff in the morning (light being already permissive) and light cuts off flight in the evening while temperature is still permissive (102). The reverse tends to occur for crepuscular and nocturnal fliers.

Sudden mass flights occur for several reasons. Most day-fliers (the most widely dispersing species) develop into flight-mature adults at a lower temperature than that permitting flight, and a cold period causes more adults to mature than can fly. When warm, these take off en masse. Supraoptimal temperatures have a similar effect. These delays have been described for $A$. fabae (84), dragonflies (34), the beet leafhopper, Circulifer tenellus (Baker) (97), Aleyrodes brassicae (Walker) (92), and Limothrips cerealium (101). Some hibernating insects also need a temperature-dependent flight maturation period [thrips (100); Dendroctonus pseudotsugae (7)] but are released only when the temperature rises above the takeoff threshold, causing sudden mass flights over wide areas of country (145).

Flying insects that are normally high in the air may become concentrated 
in dense swarms near the ground by the atmospheric stability in inversions (81), by downdrafts associated with the passage of cold fronts $(61,70)$, or by convergent winds as at the Inter Tropical Convergence Zone (124). This can be the reverse of dispersal, but nevertheless part of the same process. All such flights give a subjective but erroneous impression of a sudden response to goals or to adversity.

\section{Factors Affecting the Numbers of Insects \\ Flying, Especially in Relation TO Weather}

"Flight activity" is a universal term a mong entomologists. However, the concept is dubious and misleading, and the term is used to describe several different, and even opposite things, namely, total insects in the air (170); the proportion of a population flying (169); the rate of takeoff (67) or of landing per unit time (both of different and of the same individuals); and of the duration of flight $(131,132)$. The last three alone are conflicting, more of one causing less of the other, and therefore not related to external causes in the same way.

"Activity," conceived as changes in proportion of a population flying, caused by differences in the flight response of its individual members harks back to a metabolic concept when temperature was thought to affect aerial numbers reversibly more or less through the metabolism of insects obeying the van t'Hoff Law $(131,132)$. This concept is partly responsible for the use of linear regression analysis of field data, a quite inappropriate approach for anything but empirical prediction; for the individuals themselves do not respond kinetically in a simple, reversible way, apart from complications arising from their adaptation to stimuli $(40,41,67)$ and from the collective expression of their responses in nature.

For example, the minimum temperature needed for takeoff is usually two or three degrees higher than that needed to keep the insect flying; a drop in temperature does not always cause an insect to alight $(6,28)$. Alighting depends on the opportunities presented (denied to high-flying insects); whether these are seized depends on previous flight experience, age, sexual condition, and other internal states, but little on temperature while this is above the free-flight threshold. The takeoff response itself in relation to temperature, pressure, or light, varies as the insect adapts to these factors and the number of takeoffs per unit time is not necessarily related to any of them consistently in a population (28). The collective response is even more complex. A single species has a certain mean temperature threshold for takeoff (of ten about $17^{\circ} \mathrm{C}$ ); the values for individuals are distributed more or less symmetrically, two to three degrees on either side of this mean threshold (152). As temperatures rise from dawn onward through this range, the number of individuals taking off per unit of time increases until the mean temperature is reached when this rate diminishes to zero at the maximum in- 
dividual threshold. Provided the insects remain flying (though not necessarily remaining in the same locality!) the total numbers airborne increase sigmoidally; further increases in temperature do not increase numbers flying unless optimal temperatures are surpassed $(152,170)$. Thus, the relation of total numbers flying at any time to temperature is not linear within a day. though scattered or transformed raw data may make it appear so. Such apparent linearity can be greatly emphasized, especially over a wide temperature range when several species are present, each with a different but overlapping threshold range. The same principle is also true for light and probably for pressure.

Apart from all of these effects, however, the greatest factor, of ten outweighing changes in individual behaviour, is the effect of population changes. Though these changes are well recognized as long-term trends over several days and even corrected for (169), their rapidity from hour to hour (when they can simulate the effects of individual responses as far as aerial density change is concerned) is not so well recognized. Downdrafts that concentrate insects locally have already been mentioned; the reverse happens when insects are swept aloft. A locality is constantly changing its general insect fauna in this way, even within an hour, so rapid and all-pervading is the aerial dispersal system.

This can happen to individuals of a single species, especially at a source where dispersal is most active, and changes in numbers remaining and available for takeoff can change violently from hour to hour as gushes of new alatae appear. "Pileups" that develop as temperature falls, disperse suddenly when it rises, and thus deplete the local population in a way not susceptible to regression analysis with current weather. This process affects the shape of the daily flight curve by successive depletion (84). The habit of tacitly regarding rapid changes in aerial numbers as reflections of immediate individual flight-responses dies hard and is not yet abandoned. It sprang from a physiological approach and is continued when laboratory work on insect cultures, no matter how excellent, is extrapolated to natural populations in the field.

To summarize, aerial numbers may be affected by events at the birthplace of adults where dispersal mostly begins, or at some other place where it continues. This leads us to consider the nature of migratory and other types of flight and how it affects the displacement of insects.

\section{The Migratory Flight}

In 1906 Pearson \& Blakeman, following Ronald Ross' work with mosquitoes, developed a mathematical theory of random migration which depended on the supposed existance of two kinds of flight (115). Relatively long "flights" from "locus of origin to breeding ground or again from breeding ground to breeding ground if the species reproduced more than once"; and "flitters" or mere to and fro movements near the habitat [called major 
and minor "vicissitudes" by Ross, and migratory and trivial flights by Heape (69) and Southwood (144)]. This rough classification is undoubtedly based on fact.

The characteristics of these long displacement "flights," commonly occurring following initial exodus by new adults, are well established by innumerable field observations. They are very spectacular, particularly with butterflies and locusts because they can be seen, and are characterized by a relative persistence and undistractedness compared with other flights made by the same species. Stimuli which, at other times would provoke settling, feeding, mating, and egg-laying, have little or no effect. Feeding is often unnecessary for there is usually a plentiful supply of stored fuel; the insects have either mated or delay it till much later, and the lack of ripe eggs delays oviposition. Settling is brief or absent. The impression is given of "flight for flight's sake" "unconsumated" by any other act, "nonappetitive." However, on some very lengthy flights, fuel is replenished by feeding (110, 163).

The duration and progress of this flight away from the birthplace is adapted to the needs of particular species, varying from a few yards [termites, white fly (92)] to thousands of miles (locusts; monarch butterflies) can be resolved in to four components: fuel supply; duration of single flights; and duration of period when such flights are repeatable; and orientation.

Fuel.-Intrinsic flight duration in terms of fuel has been closely studied with many insects in tethered flight $(74,120)$. But such studies do not necessarily denote performance in nature, where insects are free to orientate in different ways or to settle permanently, long before fuel is exhausted. Thus A. fabae can make tethered flights as long as $12 \mathrm{hr}$ (29), but in free flight rarely flies for more than 2 or $3 \mathrm{hr}(81,89)$. Conversely, flights in nature may last much longer than that calculated intrinsically (159). This suggests that a small proportion of extraordinary individuals, with the help of an abnormal frequency of up-currents are frequently dispersed well beyond the expected maximum range.

The inter-relationship of fight and settling. - The duration of single flights depends not so much on fuel as on the neuro physiological state of the insect. Flight and settling are functionally inter-related, the duration of the one depending on that of the other. Most experimental work on this vital aspect of dispersal and migration has been done with free-flying Aphis fabae by Kennedy \& Booth $(89,90)$, and also with nonmigrant saturniid moths by Blest $(11,15)$.

$A$. fabae will not normally remain on the plant on which it was born even if the plant is suitable. A short flight of a few minutes, long before much fuel is used, induces it to settle and to feed. The proportion of aphids settling and the duration of rest, increases in direct proportion to the duration of the previous flight. Thresholds for stimulating takeoff and flight are low at the end of the teneral period, those for settling are high. Flight progres- 
sively lowers the response thresholds for settling until the stimuli that induce it override those which stimulate flight (87). A similar, linear relation exists in the Saturniidae. The variable waggle-dance of honey bees also is linearly related to flight duration (15), thus communicating distances flown to other bees. Other responses, principally feeding, egg-laying, and of ten mating, follow settling, and flight is therefore of ten needed to prime them (83).

Kennedy (87) conceives of the insect as acting in terms of Sherrington's theory of "successive induction" between antagonistic reflex groups; the reflex system concerned with settling is inhibited by that concerned with flight until by a reciprocal action the situation is reversed. "Nonappetitive" or undistracted flight, in Sherringtonian terms, is the stage before the "visceral effectors take over from skeletal muscle" so that flight is prolonged or emphasized at the expense of the antagonistic system beyond the "normal" time, and that stimuli which, at other times would provoke settling have no effect. A problem then is to discover what tips the balance in favour of a more or less prolonged lowering of flight thresholds with a simultaneous raising of settling thresholds, characteristic of insects in the migrant state and in contrast to those flying in a so-called "appetitive" state.

Not much is known about how insects migrating in nature react to known stimuli presented to them deliberately. Consequently, any particular insect seen flying in the field can only be designated as migratory when this is extremely obvious. There remain many flights which, though appearing to be "migratory" (in the behavioural sense of Kennedy) would be terminated if the appropriate stimuli were present. Chafers and other insects in Type II may come into this category. Until more is known of orientated, mass flights of sexually mature insects [e.g., some dragonflies (34)] they cannot be classified as migratory in the behavioural sense. But the whole transfer from source to destination includes a terminal "appetitive" phase when the habitat is located. Defined ecologically, "migration" could legitimately include this phase.

The duration of the displacement period in adult life.-Experiments on tethered flight rarely consider the effects of age or sexual condition on flight duration. Sexually immature females of $S$. gregaria fly best, and very young and sexually mature insects fly poorly (163). The maximum duration of single flights by Drosophila funebris occurred between about the third and tenth day of life and declined rapidly thereafter to death, about a month later (171). Female Oscinella frit behave similarly, but also make long flights between laying eggs (134). With heteroecious aphids, flight is limited to the first few days of life after which flight muscles autolyze; several scolytids have a limited flight period early in life for the same reason though some can fly again after the muscles regenerate. The above are examples of insects emerging as sexually immature adults. Several species of moth emerge sexually mature but fly best early in life and again lengthily after laying 
some eggs $(45,59,60,61)$. Several species of nonmigratory grasshoppers flew longest when between three days and three weeks old and when sexually mature but not gravid (126).

Observations in nature suggest that insects of different orders make the most lengthy and undistracted flights when females are sexually immature; and that after the ovaries are fully mature flights are shorter and more local. Waloff \& Bakker (160) have demonstrated this recently also with several Heteroptera.

Some long distance flights, however, occur between successive egg-laying as with the spruce bud-worm (61), locusts $(118,119)$, frit fly (134), and aphids between larviposition. Dragonflies occasionally fly en masse back to oviposit (34) and chafers fly back and forth between oviposition and feeding sites (135), though the last two are not examples of dispersal.

Diptera are especially interesting and probably depart more generally from the habit of exclusively prereproductive migration than do other orders, for much of their dispersal is also inter-reproductive. Nevertheless, long flights and much (perhaps most) dispersal is reported as prereproductive in some mosquitoes (121, 122), Prosimulium mixtum (38), Culicoides impunitatus (Goetghebuer) (127), and frit fly (134). These, like muscid flies (105), also disperse inter-reproductively, or like some mosquitoes, sometimes fly for long distances af ter a blood-meal following the post-teneral flight (54). Little is known of the undistractibility of such flights, i.e., whether the displacement is mainly inadvertent before effective stimuli for settling are encountered, or whether the stimuli are present but ineffectual.

In general, therefore, the main period of undistracted, lengthy flying spe:cifically adapted for displacement and dispersal of populations, especially from the former breeding site, occurs during the first preoviposition period. This flight is largely controlled by the length of the preoviposition period (even when this is interrupted by hibernation), and ends when females be:come sexually mature. This has obvious adaptive features associated with the distances between possible habitats: thus, S. gregaria and Danaus plexippus, with their long preoviposition periods, are geared to flights of hundreds, even thousands, of miles. Aphids, with ubiquitously distributed hosts, have a very short prereproduction period of some hours.

Thus, two facets are open to study: the effect of age, per se, on flight; and the effect of sexual condition which is correlated with age. There is no doubt that some species (e.g., Ascia monuste) migrate only when sexually immature, and that, when insects become sexually mature at the birthplace, such flight is prevented (110). Other examples are given elsewhere (83) but more are needed. A major problem is to determine how much dispersal of an original population occurs at these different stages; a priori, it seems that most occurs with young adults (except for insects that hibernate) and prereproductively.

Ovarial development and undistracted flight.-It seems, therefore, that 
when ovaries are immature, or when their growth is periodically lessened between successive ovipositions, prolonged and undistracted flight occurs.

Insects with a full fuel load, no eggs to lay, and the mating finished or postponed, are left only with the alternatives either to fly or to settle. And whether the one or the other occurs depends not only on the balance between opposing reflex systems but also presumably on the absolute strength of stimuli required to start and to maintain flight as opposed to settling. Little is known of the factors that tip the balance toward one or the other of these activities, but recent work on the hopping of fif th instar locusts, though not on flight of adults, suggests a possible mechanism.

Fif th instar hoppers of $S$. gregaria are most active about midway between moults, least so prior to moulting when the prothoracic gland enlarges and its hormone, ecdysone, increases in the haemolymph. Ecdysone seems to affect the neural response thresholds for jumping. The electrical activity on the metathoracic ganglion that controls the jumping muscles decreases when the ganglion is bathed in either haemolymph from fif th instar hoppers about to moult, or with ecdysone from Bombyx pupae, though haemolymph from mid-fifth instar hoppers has no such effect (66). Even more convincing is the finding that the marching activity of hoppers decreases when these insects are given extracts of the prothoracic glands of the locusts themselves (23). The prothoracic gland disappears in pterygote insects soon after they become adult; this suggests that its permanent removal may be correlated with the great flight activity common in young adults. Moreover, it seems that migratory flight is permitted only when ovaries are unripe, that is, when corpus allatum activity is diminished; and it ceases when ovaries mature, and also when other hormones associated with oviposition begin to operate (109).

This hypothesis is open to experiment. But the idea that intense and prolonged flight or its increased frequency is part of an endocrine deficiency syndrome, also agrees with the facts that crowding and day-length, which af fect activity of the corpus allatum, are also associated with ovarial development and migration; and with the fact that the prothoracic gland diminishes after imaginal ecdysis. These will be discussed below.

There are also many other factors that increase the flight efficiency of young adults, such as the lowered wing-loading of nongravid females (163), the possible effect of diet either acting through taste thresholds (39) or by direct effect of potassium ions in the haemolymph $(47,75)$, and the accumulation of fuel reserves and their diversion to the muscles rather than to the gonads. Very important also are factors controlling particular kinds of orientation which ensure displacement.

\section{ORIENTATION}

The "problem of orientation" in dispersive and migratory processes, is no longer restricted to how, or to what apparent end, an insect keeps to a 
linear track over distances that can be followed by the eye, and assumed to continue far beyond (168). The problem involves a great variety of orientation behaviour particularly at primary exodus and at successive takeoffs when orientation is adapted to enable the insect to be displaced by air currents. To complete the process, orientation leading to the invasion of habitats at the end of displacement flight is also part of the picture which will not be discussed here.

Orientation and penetration of the boundary layer.-Many daytime and some crepuscular fliers climb steeply after takeoff with an excess of lift over forward flight, and in so doing penetrate their "boundary layer" of air near the earth within which they can largely control their track (149). Once above this, wind largely controls the track.

Aphids orientate particularly to light of short wavelengths, blue and ultraviolet, to the diffuse light of the sky and to large sources like white clouds rather than small ones like the sun (91). Many other insects have a positive phototaxis enabling them to penetrate the boundary layer and disperse by upper air currents adaptively: e.g., some Scolytidae (58), frit fly (146), and thrips (100) Aedes taeniorhynchus and Aedes cataphylla orientate to the lightest part of the evening sky and eventually move down wind $(63,94)$. Many insects in the "aerial plankton," including large ones like the moths Plusia gamma; Choristoneura fumiferana, undoubtedly do the same, though more studies are needed of orientation, especially at first exodus, in order to assess the frequency, the time in life and the proportion of individuals behaving in this way.

Orientation during displacement above the boundary layer.-The most thorough studies of orientation of dispersing insects are those with aphids flying freely in a flight chamber $(89,90)$. Studies of locusts are more concerned with aggregation than dispersal behaviour. Almost nothing is known about how other insects high in the air orientate and those flying within the boundary layer of ten cannot be followed far or accurately by eye.

After aphids take off, their positive phototaxis to light of wavelenghts below about $500 \mathrm{~m} \mu$ gradually diminishes, lift is lost and a cruising phase follows which ends in alighting. These responses vary with the kinetic state which is also affected by light (18) as it is by flight duration. Kennedy et al. (91) inferred that aphids flying near the ground in the "alighting flight" responded to both the bright, short wavelengths of the sky and to the dimmer long wavelengths from the green vegetation and were kept in an uneasy balance between them, rather than that they became negatively phototactic. Presumably, therefore, many insects high in the air are also in this state, and many continue to be displaced until downdrafts bring them near the earth and provide opportunities for settling.

Many other insects exhibit photic reversal, though this has not usually been studied especially in relation to adaptive transportation (123). $A$. taeniorhynchus does not enter ultraviolet light traps at initial exodus but does so later $(121,122)$. Spodoptera exempta (Walker) and Cydia pomonella (L..) 
are probably attracted to light during migration while sexually immature, but not to bait until older $(55,164)$. There are many descriptions of the reversal of photic responses as humidity or temperature alters $(116,117)$ which suggest that the positive phototaxis that sometimes occurs at high temperatures (or low humidities) is the factor that causes upward flight of some migrants in conditions of intense insolation (166). Trypodendron is positively phototactic only while air pressure in the proventriculus is small, but air swallowed during flight reverses the response and the insect becomes photonegative (58). Another scolytid, Blastophagus, is positively phototactic at temperatures up to $25^{\circ} \mathrm{C}$ and photonegative above that, the reaction differing in spring and autumn beetles (116). In some insects, the sign of phototaxis is associated with the endocrine balance (12). The reversal from photonegative to photopositive response is particularly significant in the emergence of migrants from hibernation sites (100). Kennedy \& Booth regard the process as primarily controlled by a central nervous balance mechanism tipped one way or the other by a variety of inputs (90).

The orientation of locusts flying in swarms has been intensively studied by Rainey. and Waloff and the complex reactions which maintain swarm cohesion have been succinctly reviewed by Haskell (65). This is, perhaps, notthe place to describe a process which is largely the reverse of dispersal.

Orientation within the boundary layer.-Some insects (e.g., M. melolontha) $(35,128)$, scolytids, and dragonflies $(32,58,72)$ fly upwards apparently phototactically but soon orientate hypsotactically to a distant object, maintaining the course even when the distant object is displaced or obscured (35, 128). The common orientation of butterflies, migrating within the boundary layer, is also apparently established visually at exodus (110). All of these insects possibly orientate to the sun or to polarized light, though this has not been proved with migrants in the field. The exodus of locusts in swarms has been well described many times. These insects are greatly influenced by each other and adopt a "gregarious alignment" (65); but there is no evidence of sun compass reactions or of phototaxis, though orientation into wind is common. The way in which reflexes of this kind are integrated in nature during exodus, dispersal and landing flights has already been briefly mentioned for aphids. Henson (72) has studied the sequence and attractively described it for the scolytid, Conophthorus coniperda; though most of its flights seem to occur within the boundary layer this not true for all scolytids (21). Pine cones containing pupae fall to the ground and the emerging adults remain in the cones thigmokinetically during the winter, (though they are positively phototactic when removed). They do not feed. Warmth, dampness, and small changes in day-length cause sudden emergence in spring; the full gut consequent to eating their way out eliminates the thigmotaxis and allows the insect to fly upwards to diffuse sources of light, but not to point sources which disorientate them. Emerging above the tree canopy, they therefore, fly horizontally, shun the sun, and fly to dark silhouettes of trees on which they land and burrow into cones where the flight muscles degen- 
erate. Thus, the long-lived adults fly for only a very short period in a rather well-defined way which is synchronized and controlled very specifically by the warmth and dampness of spring days.

Many insects disperse from the birthplace by flying within their boundary layer and seem to control their track in a more or less linear way apparently for relatively long distances against or across the wind. This has been reported particularly for butterflies, dragonflies, and syrphids; but all of these insects (even the same species) have been reported at other times at high altitudes and not in control of their track. As with locusts, the subjective impression gained at low altitudes for short periods may not tally with a synoptic picture. Nevertheless, the orientation mechanism has been little studied except with chafers (128) though there is much speculation about it. Nielsen's (110) observations with Ascia monuste suggest that pilotage by visible guide markers such as roads, telegraph poles, occurs; the insects keep in shelter behind dunes and so control their track in windy weather. Many butterflies negotiate vertical obstacles by flying up and over in a vertical plane, similar to Melolontha when encountering a barrier, suggesting orientation by celestial guides, perhaps polarized light. $M$. melolontha, on the outward prealimentary flight, orientates partly by hypsotaxis, partly by reference to the sky, and partly by a process of imprinting $(35,128)$.

The return flight.-Many migrants make a return journey either after oogenesis or af ter hibernation or aestivation. But little is known about the relative roles played by wind, and by the flight power and orientation of the insect itself, in determining the track. Very probably, such insects as Coccinellidae, Noctuidae, and Eurygaster return from mountain hibernation sites on seasonal winds $(20,64)$. But, with insects flying within the boundary layer, a reversal of orientation can determine the direction of the return journey. Thus, Melolontha reverses its direction of orientation through $130^{\circ}$ after it has become sexually mature and the return flight, unlike the prealimentary flight, is made without reference to visible objects though a sight: of the sky is necessary, and a constant course is maintained in spite of obstacles.

Recent experiments by Birukov and by Geisler $(13,56)$ on nondispersing insects may help to elucidate the orientation of some migrants. The pondskater, Velia currens (Fabricius), and the beetle, Geotrupes, do not keep a linear course when in a natural habitat, yet they have an inherent mechanism for doing so. Under a blue sky and on dry ground, Velia runs to the south constantly, by compensating for the changing position of the sun. Under a fixed artificial light it still compensates thereby changing course rhythmically. Geotrupes also has a compass reaction to polarized light unrelated to natural goals and in the absence of food scents or landmarks, runs east in the morning, west in the afternoon. Corbet (33) suggests that such a mechanism might be used by insects that return to a site they occupied before, as between roosting and feeding sites during the day; it might explain the apparently meaningless linear course of some migrants. But the long distance 
migrations involving many miles would probably be overridden by synoptic winds, unless, like $A$ scia, the insect also kept to shelter.

Orientation during migration shows diverse mechanisms adapted to special conditions and situations, and most of these mechanisms, as yet, have not been closely studied in the field. In general, however, the orientation (whether the direction is inherent or induced) seems to be adapted for getting dispersants away from the birthplace rather than to a goal, This is done either by controlling the track or by wind, and is maintained long enough to transport the insects a considerable distance. With insects adapted to being wind-blown, flight seems to be prenavigational; "goals," distracting at other times, have little effect, primarily because of the physiological condition of the insects and, secondarily, because of the force of the wind. Navigational processes are perhaps used effectively only by insects habitually flying within the boundary layer, or at the end of a wind-borne flight. But the one-way track after exodus, whether controlled by the insect or by the wind, is the best way of ensuring that the birthplace, the former territory, or a temporary oviposition site is effectively relinquished. This seems to be the prime function of orientation during the dispersal flight itself, rather than being specifically adapted for finding some hidden and mysterious goal. Synchronized with seasonal winds, such flights, nevertheless, may take the insects to suitable habitats.

\section{Aerial TRANSPORT}

Adaptive displacement per se depends on the following factors: flight speed, duration and frequency of single undistracted flights, the duration of the "migratory" period within which single long flights are made, the need and opportunity to "refuel," orientation into or out of the "boundary layer," and the state of the atmosphere. The potentiality for adaptive variation is enormous and the integration of factors can be considered only briefly.

Insects can control their track but only within a "boundary layer" whose depth depends on flight speed and wind speed (149). Whether an insect stays inside it (as all can) or whether it penetrates it adaptively to become wind-born, depends on orientation and time of flight, not on flight speed.

Displacement within the boundary layer.-Some insects normally avoid leaving the boundary layer during displacement, either by flying mainly in calm periods as at evening, or by specific orientation ( $M$. melolontha). Others sometimes migrate entirely within the boundary layer, using shelter to maintain track for many miles [Ascia monuste in Florida (110)], but at other times fly high with the wind [A. monuste in Argentina (68)]. Some species are thought to control the complete track merely because they are seen only when flying low, perhaps in a final appetitive stage after high altitude flights [frit fly (85)].

Flight within and above the boundary layer.-A complete displacement flight of ten occurs adaptively both within and above the boundary layer. Newly emerged Aedes cataphylla Dyar, a crepuscular flier, makes a typical, 
steep exodus into wind to about $12 \mathrm{ft}$. If blown backwards, optomotor responses cause turning and downwind flight (avoiding the "forbidden course" with its backward flow of retinal images). Fast and turbulent winds do not prevent young adults, from flying, though they do with older ones. After a longish flight, mosquitoes entered a valley system where slower winds and a different orientation caused them to keep to the shelter and fly along it (94). It seems that here are two phases, as flight for A.taeniorhynchus; an early flight adapted to dispersal outside, a later one to dispersal inside the boundary layer.

Gravid females of Rhyacionia buoliana, a mainly crepuscular-flying moth, fly within the boundary layer against slow winds, tending to move up out of valleys as cold evening air flows into them. There seem to be two kinds of gravid females: some, more active than others, rise to $50 \mathrm{ft}$ and become convectionally transported for many miles; laboratory work shows that the first post-teneral flight is the longest $(59,60)$. Here, again, transport depends on age, orientation, time of day, and atmospheric motion, all of which are geared to degrees of adaptiveness either for transport per se or for oviposition nearby. This insect resembles Choristoneura fumiferana in some ways, which is also transported for long distances outside the boundary layer; sometimes, more or less accidentally, low over the forest canopy in turbulent winds, sometimes by flying upward into convective storms which carry populations for 100 miles, depositing them en masse by downdrafts and rain associated with cold fronts, particularly in certain well-defined topographical areas (51, 70).

Much depends on the geographical scale of displacement, which is determined partly by the duration of the migratory period before (or between) egg-laying. Thus, many of the small insects in the aerial plankton are dayfliers with only a few hours or, at most, a day or two, of flying life. In exceptional circumstances a tiny proportion (though still large numerically), of the original population may be transported on a synoptic scale for hundreds or thousands of miles in a day or two. Elton's aphids and syrphids in Spitzbergen (48), Gressitt's insects caught over the Pacific, are day-fliers (102) that are particularly prone to convective and turbulent transport. It is not the slow flight speed that makes this likely but rather the upward flight at exodus. The majority of these small species, however, fly only for a short period before settling when downward currents bring them to earth; within an hour for frit fly, within about three hours for aphids in Britain. The vertical density profile increases in height and decreases in steepness toward mid-day as more insects are discharged, and subsides, with the flight rhythm at exodus, to nothing by evening $(81,85)$.

The shape of the verticle density profile, but not its temporal duration is explicable largely in terms of turbulent-diffusion of particles (81). Many insects enter this general circulation only three or four feet above the source beyond which the log density versus log height profile is approximately linear to at least hundreds of feet. 
It is salutory to know that densities can diminish at about the same rate between three and six feet (and, with some, in as many inches) as between 3000 and $6000 \mathrm{ft}(22,150)$. But it is a common fallacy to suppose that most insects fly close to the ground. Densities may be great near the ground but the greatest numbers are found at high altitudes. For example, at mid-day, 50 per cent of flying frit flies are normally above $1300 \mathrm{ft}(85)$ and this kind of relation is generally true (57): small densities at a great height neglect to show the total numbers at all heights, and give the erroneous impression that there are few insects high in the air.

The whole aerial system can be regarded as a large diffusion system reaching, on convective days, to thousands of feet, dispersed because of the disruptive forces of turbulence and also because individuals are discharged consecutively into this system from a source all day. Downward currents cause a dispersed "bombardment" over hundreds and thousands of square miles, hour af ter hour, day after day. This is, perhaps, the most effective way a species can scan a wide environment (85). Probably, insects with ubiquitous hosts like aphids and frit flies, though most migratory when young, need only short prereproductive or inter-reproductive flight periods. Their large and expendable adult populations with ubiquitous hosts do not need the lengthy prereproductive period of locusts or monarch butterflies which have to traverse thousands of miles of unsuitable territory between breeding places.

The longer the flight period, the longer the potential displacement. This must be seen in relation to synoptic, not local, weather. More and more migrants, once thought to control their major track, are now being associated with synoptic weather. Knowing the time and place of arrival of migrants, the winds on which the insects arrived can be back-tracked to the probable source. Plutella maculipennis (Curtis) entered the western Atlantic area and Great Britain from eastern Russia (52), Laphygma exigua (Hübner) regularly invades Britain from Morocco; both invasions involve nonstop journeys of some 2000 miles and several days. Lepidoptera such as Utethesia pulchella (Linnaeus), Itame brunneata (Thunburg), and Hippotion celerio (Linnaeus) arrived in Britain on winds from North Africa, Germany, and the Azores, respectively $(51,76)$. Locusts arrived in Britain on a weather system remarkably like that carrying $L$. exigua, accidental only in the sense that the direction was unusual. The same kind of system normally transports locusts between breeding areas; the insect's life history is geared adaptively to produce adults when convergent winds can carry populations from areas of dryness into areas of rainfall where they can survive (124). There is good reason to suppose that the normal method of transport for many, perhaps most, other species is also by wind. As with early work on locusts, subjective impressions are formed for most insects, by watching orientated flight over a limited distance. It suggests that major displacements are made by insects orientated to ecological goals. Synoptic observation and trapping continuously at high altitudes reveals another process, better adapted to needs of species in which biology and behaviour are geared to different types 
of air movement. Insects of ten accept these uncontrollable forces, and compromise with them rather than combat them. Most insects in the aeria.l plankton probably disperse adaptively rather than accidentally.

\section{POSSIBLE CAUSES OF ADAPTIVE DISPERSAL}

There are two hypotheses now extant, to explain the causes of adaptive dispersal. One supposes, with little evidence and of ten subjectively, that adults respond immediately to adversity by flying away. The other, with stronger but mostly circumstantial evidence, supposes that adversity and the factors heralding it, act ontogenetically to produce adults that are prone to migrate (83); that migratory flight is a symptom in an endocrine deficiency syndrome concomitant with early adult life and ovarial immaturity, ovarial diapause, and structural polymorphism.

\section{The First Hypothesis}

The following findings support this hypothesis: Orthoptera migrated when plants dried up and after rain $(133,157)$. Flight in solitary locusts probably was a response to humidity changes (37). L. cerealium flew en masse when grasses dried up, rather in contrast to normal, prereproductive mass flights (99). Leafhopper populations moved from cut vegetation (103). No doubt hunger often causes insects to move but perhaps more to mix than to disperse, for starved insects cannot migrate far (74). That muscles respond more to nervous stimuli as the blood potassium concentration falls seemed to explain why locusts hopped more when starved or fed on a diet poor in potassium $(47,75)$, though this was not confirmed in the field (26).

\section{The Ontogenetic Hypothesis}

This hypothesis applies, so far, only to females. The fat-body, flight-muscle enzyme systems, and wing-loading are peculiar in migrants. But relatively undistracted flight might be caused by low neural response thresholds for flight, concomitant with lessened activity of the prothoracic glands and also with the presence of food reserves and with sexual immaturity known to be induced by food deficiency, by crowding, or by short days mediated by the corpus allatum. Crowding is associated with food shortage and, in temperate climates, with later generations and short autumn days. Crowding produces macropterous adults among leafhoppers (93) and alatae (i.e.., flight) instead of apterae with some aphids, associated probably with corpus allatum activity (98). Locusts bred in crowds are more active and have smaller prothoracic glands than do solitaries (46). Crowded Barethra brassica L. larvae produce active adults (73). In large populations of $A$. monuste, settling thresholds are so high that the insects continue to fly all night (darkness usually suppresses flight) and into the second day, scarcely stopping more than a few seconds to feed, which prolonged flight makes necessary: this behaviour is associated with delayed ovarial development (110). Aleyrodes brassicae emerges with immature ovaries in autumn and migrates 
beyond the crop, flying during the day and the night, in contrast to earlier, nonmigratory day-flying, sexually mature generations (92).

Danaus plexippus behaves similarly on a geographical scale (156). The preoviposition flight period of locusts lasts for weeks, refuelling is obligatory, and settling response thresholds relatively high. The reasons for ovarial delay are obscure but crowding induces it in Locusta migratoria migratorioides (R. \& F.) though not in $S$. gregaria and some other insects $(78,111)$.

The crowding of $C$. fumiferana larvae creates a diet change which produces sexually immature females that fly upward (14). Crowding in Callosobruchus maculatus (Fabricius) results in sexually immature, flight-worthy adult beetles with low wing-loading, while under solitary conditions the beetles emerge mature and cannot fly (25). Deficient food delays ovarial development in many migrants (79) whose flight has not been studied in relation to it.

Temperature and photoperiod affect corpus allatum activity, and macroptery and brachyptery are associated with this $(19,143,165)$. Short photoperiods delay ovarial development and induce ovarial diapause (111) but its concomitant effects on flight behaviour have been almost completely neglected in favour of the more obvious morphometric changes. Photoperiod, together with the seasonal incidence of periods above the flight threshold temperature probably decide, respectively, the length of the preoviposition period and how much of it can be used in flying, and therefore how much migration occurs before or after hibernation. Ontogenetic, environmental factors may affect the numbers and quality of adaptive dispersants at the source. At one extreme, alatae, instead of apterae, are born, ranging through degrees of brachyptery. But, at the other extreme, perhaps involving most species where little structural polymorphism exists, delayed ovarial development and the associated differences in flight seem to be concomitant symptoms of the same endocrine deficiency syndrome, and may be far more important, though less obvious than structural differences (83). 


\section{LITERATURE CITED}

1. Abbott, C. H. A quantitative study of the migration of the painted lady butterfly Vanessa cardui L. Ecology, 32, 155-71 (1951)

2. Adkin, R. Dispersal of butterfies and other insects. Nature, 116, 467 (1925)

3. Ainslie, C. N. Papers on cereal and forage insects. The New Mexico range caterpillar (Hemileuca oliviae Ck1.) U. S. Dept. Agr., Bur. Entomol., No. 85, 59-96 (1910)

4. Andrewartha, H. G., and Birch, L. C. The Distribution and Abundance of Animals. (University of Chicago Press, Chicago, Ill., 782 pp., 1954)

5. Atkins, M. D. Observations on the flight, wing movement and wing structure of male Priacma serrata (Lec.) Can. Entomologist, 90, 33947 (1958)

6. Atkins, M. D. A study of the flight of the Douglas-Fir beetle Dendroctonus pseudotsugae Hopk. III. Flight capacity. Can. Entomologist, 93, 46774 (1961)

7. Atkins, M. D., and Farris, S. H. A contribution to the knowledge of flight muscle changes in the Scolytidae. Can. Entomologist, 94, 25-32 (1962)

8. Balch, R. E. The outbreak of the European spruce sawfly in Canada and some important features of its bionomics. J. Econ. Entomol., 32, 412-18 (1939)

9. Baldwin, W. F., Riordan, D. F., and Smith, R. W. Note on clispersal of radio-active grasshoppers. Can. Entomologist, 90, 374-76 (1958)

10. Ballard, E., and Evans, M. G. Dysdercus sidae (Montr.), in Queensland. Bull. Entomol. Res., 18, 405-32 (1928)

11. Bastock, M., and Blest, A. D. An anlaysis of behaviour sequences in Automeris aurantiaca Weym. Behaviour, 12, 243-84 (1958)

12. Beetsma, J., de Ruiter, L., and de Wilde, J. Possible influence of neotinine and ecdyson on the sign of phototaxis in the eyed hawk caterpillar (Smerinthus ocellatus L.). J. Insect Physiol., 8, 251-57 (1962)

13. Birukov, G. Innate types of chronometry in insect orientation. Cold Spring Harbour Symp. Quant. Biol., 25, 403-12 (1960)

14. Blais, J. R. Effects of the destruction of the current year's foliage of bal- sam fir on the fecundity and habits of flight of the spruce budworm. Can. Entomologist, 85, 446-48 (1953)

15. Blest, A. D. Interaction between con secutive responses in a Hemileucid moth, and the evolution of insect communication. Nature, 181, 107778 (1958)

16. Blunck, H. Beobachtungen ïber Wanderflüge von Pieris brassicae $\mathrm{L}$. Beitr. Entomol., 4, 485-528 (1954)

17. Bodenheimer, F. S., and Swirski, E. The Aphidoidea of the Middle East. (The Weismann Science Press of Israel, Jerusalem, 378 pp., 1957)

18. Booth, C. O. Photokinetic function of aphid antennae. Nalure, 197, 2656 (1963)

19. Brinkhurst, R. O. The British distribution of the water.bug Velia saulii Tarnanini with some notes on alary polymorphism. Proc. Roy. Entomol. Soc. London, 35, 91-92 (1960)

20. Brown, E. S. Notes on the migration and direction of flight of Eurygastir and $A$ elia species and their possible bearing on invasions of cereal crops. J. Animal Ecol., 34, 93-107 (196!)

21. Calnaido, D. The flight and dispersal of shot-hole borer of tea. Entomol. Exptl. Appl. (In press)

22. Calnaido, D., French, R. A., and Taylor, L. R. Low altitude flight of Oscinella frit L. J. Animal Ecol.. 34, 45-61 (1965)

23. Carlisle, D. B., and Ellis, P. E. Prothoracic gland and gregarious behaviour in locusts. Nature, 200, 60:34 (1963)

24. Casimir, M. Migration and utilization of reserve substances during flight in Aphis craccivora Koch. Proc. Linnean Soc. N. S. Wales, 83, 16.572 (1958)

25. Caswell, G. H. Observations on the biology of Callosobruchus maculatus F. Divl. Rept. Fac. Agr. Univ. Coll. Ibadan (Entomol.), 3, 9 (1956); Rev. A ppl. Entomol., Ser. A, 46, 212 (1958)

26. Chapman, R. F. A field study of the potassium concentration in the blood of the red locust Nomadacris septemfasciata (Serv.) in relation to activity. Animal Behav., 6, 60-9 (1958)

27. Chapman, J. A., and Kinghorn, J. M. Studies of flight and attack activity of the Ambrosia beetle, Trypoden- 
dron lineatum (Oliv.), and other scolytids. Can. Entomologist, 90, 362-72 (1958)

28. Cockbain, A. J. Low temperature thresholds for flight in Aphis fabae Scop. Entomol. Exptl. Appl., 4, 21119 (1961)

29. Cockbain, A. J. Fuel utilization and duration of tethered flight in $A$ phis fabae Scop. J. Expll. Biol., 38, 16374 (1961)

30. Common, I. F. B. A study of the ecology of the adult Bogong moth, Argotis infusa (Boisd.) with special reference to its behaviour during migration and aestivation. Aus. tralian J. Zool., 2, 223-63 (1954)

31. Cook, W. C. The relation of spring movement of the beet leafhopper (Eutettix tenellus Baker) in central California to temperature accumulations. Ann. Entomol. Soc. Am., 38, 149-62 (1945)

32. Corbet, P. S. The life-history of the emperor dragonfly $A$ nax imperator Leach. J. Animal Ecol., 26, 1-69 (1957)

33. Corbet, P. S. (See Ref. 13)

34. Corbet, P. S. A Biology of Dragon flies. (Witherby, London, 247 pp., 1962)

35. Couturier, A. La faculté d'orientation du manneton commun Melolontha melolontha L. Z. Angew. Entomol., 50, 66-70 (1962)

36. Crichton, M. I. Observations on the longevity and dispersal of adult Limnephilidae. Proc. in Intern. Congr. Entomol., 11th, Vienna, 1960, Bd.I. (1961), 356-71 (1961)

37. Davey, J. T. The African migratory locust (Iocusta migratoria migratorioides Rch. \& Frm.) in the Central Niger Delta, Pt. 2. The Ecology of Locusta in the semi-arid lands and seasonal movements of populations. Locusia, (Nogent-sur-Marne) 7, 1-180 (1959)

38. Davies, L. Ecology of two Prosimulium species with reference to their ovarian cycles. Can. Fintomologist, 93, 1113-40 (1961)

39. Dethier, V. G., and Bodenstein, D. Hunger in the blowfly. Z. Tierpsychol., 15, 129-40 (1958)

40. Digby, P. S. B. Flight activity in the blowfly, Calliphora erythrocephala, in relation to light and radiant heat with special reference to adaptation. J. Exptl. Biol., 35, 1-19 (1958)

41. Digby, P. S. B. Flight activity in the blowfly, Calliphora erythrocephala in relation to wind speed, with spe cial reference to adaptation. $J$. Exptl. Biol., 35, 776-95 (1958)

42. Dobzhansky, T., and Wright, S. Genetics of natural populations. XV. Rate of diffusion of a mutant gene through a population of Drosophila pseudoobscura. Genetics, 32, 302-24 (1947)

43. Downes, J. A., (In Williams, Cockbill, Gibbs \& Downes). The migrations and reproductive cycles of the Monarch butterfly in California in "Studies on the migration of Lepidoptera." Trans. Roy. Entomol. Soc. London., 92, 101-283 (1942)

44. Dubinin, N. P., and Tiniakov, G. G. Inversion gradients and natural selection in ecological races of Drosophila funebris. Genetics, 31, 537-45 (1946)

45. Edwards, D. K. Laboratory determinations of the daily flight times of separate sexes of some moths in naturally changing light. Can. J. Zool., 40, 511-30 (1962)

46. Ellis, P. E., and Carlisle, D. B. The prothoracic glands and colour change in locusts. Nature, 190, 36869 (1961)

47. Ellis, P. E., and Hoyle, G. A physiological interpretation of the marching of hoppers of the African migratory locust (Locusta migratoria migratorioides R. and F.) J. Exptl. Biol., 31, 271-79 (1954)

48. Elton, C. S. The dispersal of insects to Spitsbergen. Trans. Entomol., Soc., London, 289-99 (1925)

49. Fales, J. H. A field study of the flight behaviour of the tiger swallowtail butterfly. Ann. Entomol. Soc. Am., 52, 486-7 (1959)

50. Fedotov, D. M. Some observations on the internal state of imago of Eurygaster integriceps. Compt. Rend. Acad. Sci. U.R.S.S., 42, 408-11 (1944)

51. French, R. A., Long distance movements of two migrant Lepidoptera in relation to synoptic weather. Proc. Biometeorol. Congr., 3rd, Pau, 1963. (Pergamon Press, in press)

52. French, R. A., and White, J. H. The diamond-back moth outbreak of 1958. Plant Pathol., 9, 77-84 (1960)

53. Gaines, J. C. Migration and population studies of the cotton bollworm moth (Heliothis obsoleta Fab.) $J$. Econ. Entomol., 25, 769-72 (1932)

54. Garrett-Jones, C. The possibility of active long-distance migrations by Anopheles pharoensis Theo. World 
Health Organ., M.A.L.-298 (1961)

55. Geier, P. W. Physiological age of codling moth females (Cydia pomonella (L.)) caught in bait and light traps. Nature, 185, 709 (1960)

56. Geisler, M. Untersuchungen zur Tagesperiode des Mistkäfers, Geotrupes silvaticus Panz. Z. Tierpsychol., 18, 389-420 (1961)

57. Glick, P. A. The distribution of insects, spiders and mites in the air. $U$. $S$. Dept. Agr. Tech. Bull., 673, 1-150 (1959)

58. Graham, K. Air swallowing: a mechanism in photic reversal of the beetle Trypodendron. Nature, 191, 519-20 (1961)

59. Green, G. W. Flight and dispersal of the European pine shoot moth, Rhyacionia buoliana (Schiff.) I. Factors affecting flight and the flight potential of females. Can. Entomologist, 94, 282-99 (1962)

60. Green, G. W., and Pointing, P. J. Flight and dispersal of the European pine shoot moth, Rhyacionia buoliana (Schiff.) II. Natural dispersal of egg laden females. Can. Entomologist, 94, 299--314 (1962)

61. Greenbank, D. O. The role of climate and dispersal in the initiation of outbreaks of the spruce budworm in New Brunswick. Can. J. Zool., 35, 385-403 (1957)

62. Gunn, D. L., Perry, F. C., Seymour, W. G., Telford, T. M., Wright, E. N. and Yeo, D. Behaviour of the desert locust (Schistocerca gregaria Forskål) in Kenya in relation to aircraft spraying. Anti-Locust Bull. London, 3, 1-70 (1960)

63. Haeger, J. S. Behaviour preceding migration in the salt-marsh mosquito Aedes taeniorhynchus. Masquito News, 20, 126-47 (1960)

64. Hagen, K. S. Biology and ecology of predaceous Coccinellidae. Ann. Rev. Entomol., 7, 289-326 (1962)

65. Haskell, P. T. The sensory equipment of the migrating locust. Symp. Zool. Soc., London., 3, 1-23 (1960)

66. Haskell, P. T., and Moorhouse, J. E. A blood-born factor influencing the activity of the central nervous system of the desert locust. Nature, 197, 56-58 (1963)

67. Haufe, W. O. Ethological and statistical aspects of a quantal response in mosquitoes to environmental stimuli. Behaviour, 20, 221-41 (1963)

68. Hayward, K. J. Migration of butter- flies in Argentina during the spring and summer of 1951-52. Proc. Roy. Entomol. Soc. London., (A), 28, 69-. 73 (1953)

69. Heape, W. Emigration, Migration and Nomadism. (University Press, Cambridge, 369 pp., 1931)

70. Henson, W. R. Mass flights of the spruce budworm. Can. Entomologist, 83, 240 (1951)

71. Henson, W. R. Laboratory studies on the adult behaviour of Conophthorus coniperda (Schwarz) III. Flight. Ann. Entomol. Soc. Am. $55,524-30$ (1962)

72. Henson, W. R. The analysis of dispersal mechanisms in Conophthorus coniperda Sz. J. Proc. Biometeorol. Congr., 3rd., Pau, 1963. (Pergamon Press, in press)

73. Hirata, S. On the phase variation of the cabbage armyworm, Barathra brassicae. Res. Pop. Ecol. III., Contrib. Entomol. Lab. Kyoto Univ. 27:8, 79-92 (1956)

74. Hocking, B. The intrinsic range and speed of flight of insects. Trans. Roy. Entomol. Soc. London, 104, 223-345 (1953)

75. Hoyle, G. Changes in the blood potassium concentration of the African migratory locust (Locusta migratoria migratorioides R. \& F.) during food deprivation, and the effect on neuro-muscular activity. $J$. Exptl. Biol., 31, 260-70 (1954)

76. Hurst, G. W. Meteorological aspects of the migration to Britain of Laphygme exigua and certain other moths on specific occasions. Agr. Meteorol.. 1, 271-81 (1964)

77. Imms, A. D. A General Textbook of Entomology, 9th ed. (Revised) (Methuen, London, 886 pp., 1960)

78. Iwao, S. Studies on the phase variation and related phenomena in some Lepidopterous insects. Mem. Coll. Agr., Kyoto Univ. Entomol. Ser., No. 12, 1-80 (1962)

79. Johannson, A. S. Feeding and nutrition in reproductive processes in insects. Symp. No. 2: Insect Reproduction. Roy. Entomol. Soc. London, 41-55 (1964)

80. Johnson, C. G. Aphid migration in relation to weather. Biol. Rev. Cambridge Phil. Soc., 29, 87-118 (1954)

81. Johnson, C. G. The vertical distribution of aphids in the air and the temperature lapse rate. Quart. J. Roy. Meteorol. Soc., 83, 194-201 (1957) 
82. Johnson, C. G. A basis for a general system of insect migration and dispersal by flight. Nature, 186, 348-50 (1960)

83. Johnson, C. G. Physiological factors in insect migration by flight. $\mathrm{Na}$ ture, 198, 423-27 (1963)

84. Johnson, C. G., and Taylor, L. R. Periodism and energy summation with special reference to flight rhythms in aphids. J. Exptl. Biol., 34, 209-21 (1957)

85. Johnson, C. G., Taylor, L. R., and Southwood, T. R. E. High altitude migration of Oscinella frit L. $J$. Anima\} Ecol., 31, 373-83 (1962)

86. Kelly, E. O. G., and Parks, T. H. Chinch-bug investigations west of the Mississippi River. U.S. Dept. Agr., Bur. Entomol., 95(iii), 23-52 (1911)

87. Kennedy, J. S. The experimental analysis of aphid behaviour and its bearing on current theories of instinct. Intern. Congr. Entomol. Proc. 10th, 2 (1956), 397-404 (1958)

88. Kennedy, J. S. A turning point in the study of insect migration. Nature, 189, 785-91 (1961)

89. Kennedy, J. S., and Booth, C. O. Free flight of aphids in the laboratory. J.exptl. Biol., 40, 67-85 (1963)

90. Kennedy, J. S., and Booth, C. O. Coordination of successive activities in an aphid. The effect of flight on the settling responses. J. Exptl. Biol., 40, 351-69 (1963)

91. Kennedy, J. S., Booth, C. O., and Kershaw, W. J. S. Host finding by aphids in the field. III. Visual attraction. Ann. Appl. Biol., 49, 1-21 (1961)

92. El Khidir, E. Ecological studies on Aleyrodes brassicae with special reference to dispersal. (Doctoral thesis, London Univ., 1963)

93. Kisimoto, R. Effect of crowding during the larval period in the determination of the wing-form of an adult plant-hopper. Nature, 178, 641-42 (1956)

94. Klassen, W., and Hocking, B. The influence of a deep river valley system of the dispersal of A edes mosquitos. Bull. Entomol. Res., 55, 289304 (1964)

95. Lansbury, I. Note on migratory Coleoptera. Entomol. Monthly Mag., 96, 180 (1960)

96. Larsen, E. B. Activity and migration of Plusia gamma L. Studies in the activities of insects, III. Biol. Medd. K.G.K., 21, 1-32 (1949)

97. Lawson, F. R., Chamberlain, J. C., and York, G. T. Dissemination of the beet leafhopper in California. U.S. Depl. Agr., Tech. Bull., 1030, 59 pp. (1951)

98. Lees, A. D. Clonal polymorphism in aphids. Insect Polymorphism: Roy. Entomol. Soc. London, Symp. No. 1, 68-79 (1961)

99. Lewis, T. The annual cycle of Limothrips cerealium Haliday and its distribution in a wheat field. Entomol. Expil. Appl., 2, 187-203 (1959)

100. Lewis, T. The effect of weather on emergence and take-off of overwintering Limothrips cerealium Haliday. Ann. Appl. Biol., 51, 489502 (1963)

101. Lewis, T. The weather and mass flights of Thysanoptera. $A \boldsymbol{n n}$. $A \boldsymbol{p} p l$. Biol., 53, 165-70 (1964)

102. Lewis, T., and Taylor, L. R. Diurnal periodicity of flight by insects. Trans. Roy. Entomol. Soc., London, 116, 393-479 (1965)

103. Linn, M. B. The yellows disease of lettuce and endive. Cornell Univ. $A \mathrm{gr}$. Expt. Sta. Bull., 742, 1-33 (1940)

104. Macan, T. T. Notes on the migration of some aquatic insects. J. Soc. Brit. Entomol., 2, 1-6 (1939)

105. McLeod, J., and Donelly, J. Natural features and blowfly movement. $J$. Animal Ecol., 29, 85-93 (1960)

106. Medler, J. T. A note on swarming and emergence of ants. Proc. Entomol. Sac., Wash., 60, 258 (1958)

107. Milne, A. Biology and ecology of the garden chafer Phyllopertha horticola (I..). V. The flight season: sex proportions. Bull. Entomol. Res., 50, 39-62 (1959)

108. Milne, A. Biology and ecology of the garden chafer, Phyllopertha horticola (L). VI. The flight season: reproductive state of females. Bull. Entomol. Res., 50, 467-86 (1959)

109. Nayar, K. K. Probable endocrine mechanism controlling oviposition in the insect Iphita limbata Stal. Intern. Symp. Neurosekret, 2nd, Berlin 1958, 102-4 (J. Springer, Berlin, 1958)

110. Nielsen, E. T. On the habits of the migratory butterfly Ascia monuste L. Biol. Medd. Dansk Vid. Selskab., 23, 1-81 (1961)

111. Norris, M. J. Environmental control of sexual maturation in insects. Symp. No. 2: Insect Reproduction. 
Roy. Entomol. Soc. London, 56-65 (1964)

112. Nuorteva, P. Studies in the causes of the phytopathogenicity of Calligypona pellucida (F.) Ann. Zool. Soc. Zool.-Botan. Fennicae Vanamo, 23, 1-58 (1962)

113. Parker, J. R., Strand, A. L., and Seamans, H. L. Pale western cutworm (Porosagrotis orthogonia Morr.) J. Agr. Res., 22, 289-321 (1921)

114. Pearman, J. V. Biological observations on British Psocoptera. IV. Miscellaneous. Entomol. Monthly Mab., 64, 266-68 (1928)

115. Pearson, K., and Blakeman, J. Mathematical contributions to the theory of evolution $\mathrm{XV}$. A mathematical theory of random migration. Drapers Co. Mem. Biom. Ser. 3, $54 \mathrm{pp}$. (1906)

116. Perttunen, V. Seasonal variation in the light reactions of Blastophagus piniperda $\mathrm{L}$. at different temperatures. Ann. Entomol. Fennici, 26, 86-92 (1960)

117. Perttunen, V. Effect of dessication on the light reactions of some terrestrial arthropods. Orientierung der Tiere. Ergeb: Biol., 26, 90 97 (1963)

118. Popov, G. B. Notes on the behaviour of swarms of the desert locust (Schistocerca gregaria Forskål) during oviposition in Iran. Trans. Roy. Entomol. Soc. London., 105, 65-77 (1954)

119. Popov, G. B. Note on the frequency and the rate of oviposition in swarms of the desert locust (Schislocerca gregaria Forskål) Entomol. Monthly Mag., 94, 179-80 (1958)

120. Pringle, J. W. S. Insect Flight. (University Press, Cambridge, Engl., 133 pp., 1957)

121. Provost, M. W. The dispersal of A edes toeniorhynchus. I. Preliminary studies. Mosquito News, 12, 174-90 (1952)

122. Provost, M. W. The dispersal of Aedes taeniorhynchus. II. The second experiment. Mosquito News, 17, 233-47 (1957)

123. Pulliainen, E. Studies on the humidity and light orientation and the flying activity of Myrrha 18-guttata L. Ann. Entomol. Fennici, 30, 117-41 (1964)

124. Rainey, R. C. Meteorology and the migration of desert locusts. WMO No. 138. TP 64. (World Meteoro- logical Organization, Geneva). Anti-Locusl Mem., 7, 115 pp. (1964)

125. Reid, R. W. Biology of the mountain pine beetle, Dendroctonus monticolae Hopkins, in the East Koote. nay Region of British Columbia. I. Life cycle, brood development, and flight periods. Can. Entomologist, 94, 531-38 (1962)

126. Riegert, P. W. Flight of grasshoppers in the laboratory. Nature, 194, 1298-99 (1962)

127. Reuben, $R$. A comparison of trap catches of Culicoides impunctatus Goetghebuer with meteorological data. Proc. Roy. Entomol. Sox. London (A), 38, 181-93 (1963)

128. Robert, $P$. Les migrations orientées du hanneton commun Melolontha melolontha L. Ergeb. Biol., 26, 13546 (1963)

129. Rockstein, M. Metachemogenesis-postemergence biochemical misturation in insects. Studies in invertebrate morphology. Smilhsonian Inst. Misc. Collections, 137, 263-86 (1959)

130. Roer, H. Experimentelle Untersuchungen zum Migrationsverhaltien des Kleiner Fuchs (Aglais urticae L.) Beitr. Entomol., 12, 528-54 (1962)

131. Rudolfs, W. Observations on the relations between atmospheric conditions and the behaviour of mos. quitoes. New Jersey Agr. Expt. Sta. Bull., No. 388, 32 pp., (1923)

132. Rudolfs, W. Relation between temperature, humidity and activity of house mosquitoes. $J$. $N$. Y. Evitomol. Soc., 33, 163-69 (1925)

133. Rungs, $\mathrm{Ch}$. Observations d'un vol en essaim d'Aiolopus thalassinus (Fab.) Proc. Roy. Entomol. Soc. Lonidon (A), 13, 135-36 (1938)

134. Rygg, T. Flight of Oscinella frit L. females in relation to age and ovary development. Entomol. Exptl. A;ppl. (In press, 1965)

135. Schneider, F. Auftreten und Ovarialentwicklung der Maikäfer Melolontha vulgaris $\mathrm{F}$., $M$. hippocastani $F_{\text {, and }} M$. hippocastani v. nigripes Com. an der alpinen Verbreitungsgrenze im Hinterheintal. Mitt. Schweiz. Entomol. Ges., 25, 111-30 (1952)

136. Schneider, F. Dispersal and migration. Ann. Rev. Entomol., 7, 22:3-42 (1962)

137. Sheppard, P. M. A quantitative study of two populations of the moth 
Panaxia dominula (L.). Heredity, 5, 349-78 (1951)

138. Shirck, F. H. Observations on the flight of adults of the sugar-beet wireworm Limonius californicus (Mann.). J. Econ. Entomol, 32, 726 (1939)

139. Skertchly, S. B. J. Butterfly swarms. Nature, 20, 266 (1879)

140. Smith, C. E., and Allen, N. The migratory habit of the spotted cucumber beetle. J. Econ. Entomol., 25, 53-57 (1932)

141. Snow, W. E., and Pickard, E. Correlation of vertical and horizontal flight activity of Mansonia perturbans with reference to marked changes in light intensity. Ann. Entomol. Soc. Am., 50, 306-11 (1957)

142. South, $R$. Notes on Lepidoptera in the Isle of Wight, 1879. Entomologist, 13, 38-42 (1880)

143. Southwood, T. R. E. A hormonal theory of the mechanism of wing polymorphism in Heteroptera. Proc. Roy. Entomol. Soc. London (A), 36, 63-66 (1961)

144. Southwood, T. R. E. Migration of terrestrial arthropods in relation to habitat. Biol. Rev. Cambridge Phil. Soc., 37, 171-214 (1962)

145. Southwood, T. R. E., and Johnson, C. G. Some records of insect flight activity in May, 1954, with particular reference to the massed flights of Coleoptera and Heteroptera from concealing habitats. Entomol. Monthly Mag., 93, 121-26 (1957)

146. Southwood, T. R. E., Jepson, W. F., and Emden, H. F., van. Studies on the behaviour of Oscinella frit $\mathrm{L}$. adults of the panicle generation. Entomol. Exptl. Appl., 4, 196-210 (1961)

147. Sweeney, R. C. H. Cotton insect pest investigations in the Federation of Rhodesia and Nyasaland. Pt. II. Cotton Stainer investigations. $\mathrm{Em}$ pire Cotton Groveing Rev., 37, 32-44 (1960)

148. Talbot, $M$. Nest structure and flights of the ant Formica obscuriventris Mayr. Animal Behav., 12, 154-58 (1964)

149. Taylor, L. R. Aphid dispersal and diurnal periodicity. Proc. Linnean Soc. London, 160th Session 195657, Pts. 1 and 2, 66-73 (1958)

150. Taylor, L. R. The distribution of insects at low levels in the air. $J$.
Animal Ecol., 29, 45-63 (1960)

151. Taylor, L. R. Aggregation, variance and the mean. Nature, 189, 732-35 (1961)

152. Taylor, L. R. Analysis of the effect of temperature on insects in flight. $J$. Animal Ecol., 32, 99-117 (1963)

153. Tilden, J. W. General characteristics of the movements of Vanessa cardui (L.). J. Res. Lepidop., 1, 4349 (1962)

154. Tower. W. L. An investigation of evolution in the Chrysomelid beetles of the genus Leptinotarsa. Carnegie Inst. Wash. Publ., 48, 320 pp. (1906)

155. Urquhart, F. A. A discussion of the use of the word "migration" as it relates to a proposed classification for animal movements. Contrib. Roy. Ontario Museum, Div. Zool. Paleontol., No. 50, 11 pp. (1958)

156. Urquhart, F. A. The Monarch Butterfly (University of Toronto Press, 361 pp., 1960)

157. Volkonsky, M. Observations sur le comportement du criquet pélerin (Schistocerca gregaria Forsk.) dans le Sahara Algéro-Nigérien. Arch. Inst. Pasteur Algerie, 20, 236-48 (1942)

158. Wakeland, C. Flight studies of Bruchus pisorum L. J. Econ. Entomol., 27, 534-42 (1934)

159. Waloff, $Z$. A long-range migration of the desert locust from southern Morroco to Portugal, with an analysis of concurrent weather conditions. Proc. Roy. Entomol. Soc. London (A), 21, 81-84 (1946)

160. Waloff, N., and Bakker, $K$. The flight activity of Miridae living on broom, Sarothamnus scoparius (L.) Wimm. J. Animal Ecol., 32, 461-80 (1963)

161. Webster, F. M. The chinch bug: its probable origin and diffusion, its habits and development, natural checks and preventive measures, with mention of the habits of an allied European species. U.S. Dept. Agr. Bur. Entomol., No. 15, new series, 80 pp. (1898)

162. Webster, F. M. The disastrous occurrence of Vanessa californica in California and Oregon during the years 1911-1912. Can. Entomologist, 45, 117-20 (1913)

163. Weis-Fogh, T. Fat combustion and metabolic rate of flying locusts (Schistocerca gregaria, Forskål.) Phil. Trans. Roy. Soc. London, Ser. B., 237, 1-36 (1952) 
164. Whellan, J. A. Report of the chief entomologist for the year ending 30 September, 1956. Rhodesia Agr. J., 55, 302-13 (1958)

165. Wigglesworth, V. B. The physiology of insect metamorphosis. Cambridge Monographs Exptl. Biol., I. (Cambridge University Press, 152 pp., 1954)

166. De Wilde, J. The relation between diapause research and control of the Colorado beetle, Leptinotarsa decemlineata Say. Ann. Appl. Biol., 50, 606-8 (1962)

167. Wille, $H$. P. Untersuchungen über Psylle piri L. und andere Birnblattsaugenarten in Wallis. (Doctoral thesis, Tech. Hochschule, Zurich, 113 pp., 1950)
168. Williams, C. B. Insect migration. Ann. Rev. Entomol., 2, 163-79 (1957)

169. Williams, C. B. Studies in the effect of weather conditions on the activity andabundance of insect populations. Phil. Trans. Roy. Soc. London, Ser. B., 244, 331-78 (1961)

170. Williams, C. B., and Osman, M. F. H. A new approach to the problem ofi the optimum temperature for in. sect activity. J. Animal Ecol., 29, 187-89 (1960)

171. Williams, C. M., Barness, L. A., and Sawyer, W. H., The utilisation of glycogen by flies during flight anis some aspects of the physiological ageing of Drosophila. Biol. Bull. Woods Hole, 84, 263-73 (1943) 


\section{CONTENTS}

Regulation of Gene Action in Insect Development, $H$. Kroeger and $M$. Lezzi . . . . . . . . . . . . . . . 1

The Comparative Embryology of the Diptera, D. T. Anderson . 23

Polymorphism in Aphididae, D. Hille Ris Lambers . . . . . 47

Physiology of Caste Determination, $N$. Weaver. . . . . . . 79

Insect Walking, D. M. Wilson . . . . . . . . . . . . . 103

The Behavior Patterns of Solitary Wasps, H. E. Evans. . . . . 123

The Utilization and Management of Bumble Bees for Red Clover and Alfalfa Seed Production, S. Norgaard Holm. . 155

The Competitive Displacement and Coexistence Principles, P. DeBach . . . . . . . . . . . . . . . . 183

Insects in the Epidemiology of Plant Viruses, F. Ossiannilsson . 213

A Functional System of Adaptive Dispersal by Figigt, $C$. $G$. Johnson . . . . . . . . . . . . . . . . . 233

Ticks in Relation to Human Diseases Caused by Viruses, $H$. Hoogstraal . . . . . . . . . . . . . . . . 261

The Biosystematics of Triatominae, $R$. L. Usinger, $P$. Wygodzinsky and R. E. Ryckman. . . . . . . . . . . . . . 309

The Use and Action of Ovicides, E. H. Smith and E. H. Salkeld . 331

Mode of Action of Insecticides, $R$. D. O'Brien . . . . . . . . $\quad . \quad 369$

Chemical Insect Attractants and Repellents, M. Jacobson . . 403

Fungal Parasites of Insects, M. F. Madelin . . . . . . . . . 423

The Role of Vertebrate Predators in the Biological Control of Forest Insects, C. H. Buckner . . . . . . . . . . . . . . . . 449

Management of Insect Pests, $P$. W. Geier. . . . . . . . . . . 471

Tea Pests and Their Control, J. E. Cranham . . . . . . . 491

Pest Control, J. V. Osmun and W. L. Butts . . . . . . . . . 515

Author INDEX . . . . . . . . . . . . . . . . . . . . . . 549

SUBJECT INDEX

Index of Contributing Authors . . . . . . . . . . . . . . 589

INDEX OF CHAPTER TITLES . . . . . . . . . . . . . . 591 